\title{
Recommendations for Minimal Laboratory Testing Panels in Patients with COVID-19: Potential for Prognostic Monitoring
}

\author{
Emmanuel J. Favaloro, PhD, FFSc (RCPA) ${ }^{1}$ Giuseppe Lippi, MD ${ }^{2}$
}

\author{
${ }^{1}$ Department of Haematology, Sydney Centres for Thrombosis and \\ Haemostasis, Institute of Clinical Pathology and Medical Research, \\ NSW Health Pathology, Westmead Hospital, Westmead, New South \\ Wales, Australia \\ ${ }^{2}$ Section of Clinical Biochemistry, Department of Neuroscience, \\ Biomedicine, and Movement, University of Verona, Verona, Italy
}

Semin Thromb Hemost 2020;46:379-382.

A new infective outbreak, which has been finally defined as coronavirus disease 2019 (COVID-19), has now taken hold all around the world. ${ }^{1}$ Although this is recognized as a viral respiratory illness caused by severe acute respiratory syndrome coronavirus 2 (SARS-CoV-2), the pathophysiology of the disease is far wider than respiratory, including long-term risk for adverse cardiovascular disease, thromboembolic disorders, and multiple organ failure (MOF). ${ }^{2}$ The initial clinical course of the respiratory disease can be complicated by the development of interstitial pneumonia in a considerable number of patients, evolving toward acute respiratory distress syndrome in up to 10 to $15 \%$ of these, who will then require mechanical ventilation or intensive care. ${ }^{3}$ Increasingly recognized, however, is the potential for the development of some forms of thrombotic coagulopathies including intravascular disseminated coagulation (DIC) in a subset of patients and indeed also being prognostic for poor morbidity and mortality. ${ }^{4,5}$

Based on our understanding of the emerging literature, we aim to provide in this short commentary a simple list ( - Table 1 ) of laboratory tests, as may be recommended for patients with COVID-19 and to potentially assist in prognostic monitoring of such patients. The rationale for the listing is also provided and based on recent reports around clinical and laboratory features of COVID-19 affected patients. ${ }^{4-11}$ However, we recognize that such a list is time-relevant and potentially time-limited and may quickly change as new information emerges. Thus, at all times, local experts should be consulted as available and testing modified accordingly. As an example, antithrombin is noted as lower in COVID-19 cases than in controls ${ }^{11}$; however, there is no current evidence that antithrombin is differentially lower in severe cases and thus may not have clear prognostic value. As another example, the extent of thrombocytopenia does
Address for correspondence Emmanuel J. Favaloro, PhD, FFSc (RCPA), Department of Haematology, Sydney Centres for Thrombosis and Haemostasis, Institute of Clinical Pathology and Medical Research, NSW Health Pathology, Westmead Hospital, Corner Darcy and Hawkesbury Rd, Westmead, New South Wales 2145, Australia (e-mail: emmanuel.favaloro@health.nsw.gov.au).

seem to be associated with the severity of disease ${ }^{12}$ and thus has been included in - Table 1. On the other hand, there is considerable interaction between platelets and viruses, ${ }^{13}$ and therefore an assessment of other platelet indices may also become relevant in the future.

Thus, currently, we recommend a minimum test panel for hematology comprising (1) a complete or full blood count ( $\mathrm{CBC} / \mathrm{FBC}$, representing the United States, European, United Kingdom, Australian nomenclature), (2) routine coagulation tests (prothrombin time [PT] and activated partial thromboplastin time [APTT]), (3) fibrinogen, and (4) D-dimer (optional: other associated tests such as fibrin/fibrinogen degradation products and fibrin monomers as locally available or supported). We also recommend a series of biochemistry and other tests (-Table $\mathbf{1}$ ), including markers for inflammation, electrolyte disturbance, liver dysfunction, and renal and cardiac damage, which would reflect the development of viral sepsis, systemic inflammatory response syndrome, and/or MOF, which are all conditions associated with an extraordinarily enhanced risk of thrombotic coagulopathies.

Our recommendations in part relate to emerging evidence that intravascular coagulation, inclusive of DIC, is a feature of poor prognosis in seriously affected patients. ${ }^{4-11}$ Also widely recognized is worsening organ damage, even death. Our recommendations are tempered by our expertise in the area of hemostasis and biochemistry, and therefore some gaps are unavoidable.

Nevertheless, several lines of evidence now attest that elevation of thrombotic biomarkers, especially D-dimer, is commonplace in patients with COVID-19, ${ }^{4-11}$ especially in those with more severe disease. ${ }^{4}$ Therefore, routine monitoring of D-dimer and other useful tests such as PT, APTT, fibrinogen, published online April 12, 2020
Issue Theme Acquired Platelet Dysfunction-Laboratory and Clinical Implications; Guest Editors: Anne-Mette Hvas, MD, PhD, Julie Brogaard Larsen, MD, $\mathrm{PhD}$, and Leonardo Pasalic, MBBS, PhD.
Copyright $\odot 2020$ by Thieme Medical Publishers, Inc., 333 Seventh Avenue, New York, NY 10001, USA. Tel: +1(212) 760-0888.
DOI https://doi.org/ 10.1055/s-0040-1709498. ISSN 0094-6176. 
Table 1 Recommendations for laboratory tests in patients with COVID-19a

\begin{tabular}{|c|c|c|c|}
\hline Test & Abbreviation & Rationale for inclusion & Considerations \\
\hline \multicolumn{4}{|c|}{ Hematology (including hemostasis/coagulation) } \\
\hline Complete/full blood count & $\mathrm{CBC} / \mathrm{FBC}$ & $\begin{array}{l}\text { Identification of lymphopenia, } \\
\text { neutrophilia, and thrombocytopenia }\end{array}$ & $\begin{array}{l}\text { Include platelet count, } \\
\text { differential for } \\
\text { lymphocyte count }\end{array}$ \\
\hline Prothrombin Time & PT & \multirow{2}{*}{$\begin{array}{l}\text { Identification of ongoing } \\
\text { coagulopathy }\end{array}$} & \\
\hline $\begin{array}{l}\text { Activated partial } \\
\text { thromboplastin time }\end{array}$ & APTT & & \\
\hline Fibrinogen & Fbg or Fib & $\begin{array}{l}\text { Identification of ongoing } \\
\text { (consumption) coagulopathy }\end{array}$ & \\
\hline D-dimer & & $\begin{array}{l}\text { Identification of ongoing } \\
\text { (consumption or thrombotic) } \\
\text { coagulopathy }\end{array}$ & b \\
\hline \multicolumn{4}{|l|}{ Biochemistry and other tests } \\
\hline Electrolytes & & \multirow{2}{*}{$\begin{array}{l}\text { Identification of metabolic } \\
\text { derangement }\end{array}$} & \\
\hline Glucose & & & \\
\hline C-reactive protein & CRP & $\begin{array}{l}\text { Monitoring of infection/ } \\
\text { inflammatory response }\end{array}$ & b \\
\hline Lactate dehydrogenase & $\mathrm{LDH}$ & $\begin{array}{l}\text { Identification of lung injury } \\
\text { and/or multiple organ failure }\end{array}$ & \\
\hline Aspartate aminotransferase & AST & \multirow[t]{3}{*}{ Identification of liver injury } & \\
\hline Alanine aminotransferase & ALT & & \\
\hline \multicolumn{3}{|l|}{ Bilirubin } & \\
\hline Albumin & & Identification of liver failure & \\
\hline $\begin{array}{l}\text { Creatine kinase (also known as } \\
\text { creatine phosphokinase or } \\
\text { phosphocreatine kinase) }\end{array}$ & CK & Identification of muscle injury & \\
\hline Lipase & & Identification of pancreatic injury & \\
\hline blood urea nitrogen & BUN & \multirow[t]{2}{*}{ Identification of kidney injury and/or failure } & \\
\hline Creatinine & & & \\
\hline $\begin{array}{l}\text { Cardiac biomarkers } \\
\text { (troponin I or } \mathrm{T} \text { ) }\end{array}$ & & Identification of cardiac injury & $\mathbf{b}$ \\
\hline Brain natriuretic peptide & BNP & Identification of cardiac failure & c \\
\hline Ferritin & & Monitoring of infection/inflammatory response & b \\
\hline Procalcitonin & PCT & Identification of bacterial coinfections & $\mathrm{b}$ \\
\hline Presepsin & & Monitoring of severity of viral infection & d \\
\hline
\end{tabular}

Abbreviation: COVID-19, coronavirus disease 2019.

${ }^{a}$ These tests may have some prognostic value in COVID-19 patients. However, we recognize that such a list is time-relevant and potentially time-limited and may quickly change as new information emerges. Thus, at all times, local experts should be consulted as available and testing modified accordingly.

b“Gating rule": unless clinically justified, testing should not generally be reordered within 24 hours of an existing test.

${ }^{\mathrm{C}}$ For selected patients with signs of MOF/SIRS; discuss with an expert (laboratory) clinician/senior or clinical scientist.

${ }^{\mathrm{d}}$ For patients under intensive care.

and platelet count would help to rapidly and accurately detect patients at a higher risk or those who have already developed DIC as well as venous thromboembolism, and whereby different clinical management may be required according to clinical settings.

This is, for example, supported by evidence published by Tang et al, showing that most hospitalized patients with COVID-19 who died match criteria for a diagnosis of DIC (i.e., $\sim 71$ vs. $<1 \%$ in survivors), ${ }^{5}$ a finding that was also later confirmed in a subsequent study of Han et al. ${ }^{11}$ To some extent, the situation with COVID-19 reflects a similar, albeit seemingly worse, coagulopathic risk than other viruses. ${ }^{14-16}$

Whether an early establishment of antithrombotic treatment in patients with severe COVID-19 would be beneficial to prevent (at least) thrombotic coagulopathies remains largely unexplored and indeed should be the subject of urgent studies. Although glycosaminoglycans (thus including heparins) also have some antiviral activities ${ }^{17}$ and would thus seem promising therapeutic agents in COVID-19, the identification of the most appropriate antithrombotic treatment, maximizing 
benefits and possessing the best balance between bleeding and thrombotic risk in such patients, reflects another compelling need at this time.

\section{Caveats}

The recommendations are not intended for implementation in all patients who have tested positive for COVID-19, for example, people with mild disease who have self-isolated at home, but rather for hospitalized patients with potentially severe disease. The information provided here is for guidance only and is based on our understanding of the emerging literature at the time of writing. As the information is timerelevant and potentially time-limited, such guidance may quickly change as new information emerges. Thus, at all times, local experts should be consulted as available and testing modified accordingly. The opinions in this commentary are those of the authors and not necessarily those of the University of Verona or NSW Health Pathology.

\section{Conflicts of Interest}

None.

\section{References}

1 World Health Organization. Coronavirus disease 2019 (COVID19) situation report - 43. Available at: https://www.who.int/ emergencies/diseases/novel-coronavirus-2019/situationreports/. Accessed March 4, 2020

2 Driggin E, Madhavan MV, Bikdeli B, et al. Cardiovascular considerations for patients, health care workers, and health systems during the coronavirus disease 2019 (COVID-19) pandemic. JAMA 2020 (e-pub ahead of print). Doi: 10.1016/j.jacc.2020.03.031

3 Mattiuzzi C, Lippi G. Which lessons shall we learn from the 2019 novel coronavirus outbreak? Ann Transl Med 2020;8(03):48

4 Lippi G, Favaloro EJ. D-dimer is associated with severity of coronavirus disease 2019 (COVID-19): a pooled analysis. Thromb Haemost 2020. DOI: $10.1055 / \mathrm{s}-0040-1709650$ [epub ahead of print]

5 Tang N, Li D, Wang X, Sun Z. Abnormal coagulation parameters are associated with poor prognosis in patients with novel coronavirus pneumonia. J Thromb Haemost 2020 (e-pub ahead of print) . Doi: $10.1111 /$ jth. 14768

6 Lippi G, Plebani M. Laboratory abnormalities in patients with COVID-2019 infection. Clin Chem Lab Med 2020 (e-pub ahead of print) . Doi: 10.1515/cclm-2020-0198

7 Huang C, Wang Y, Li X, et al. Clinical features of patients infected with 2019 novel coronavirus in Wuhan, China. Lancet 2020;395 (10223):497-506

8 Wang D, Hu B, Hu C, et al. Clinical characteristics of 138 hospitalized patients with 2019 novel coronavirus-infected pneumonia in Wuhan, China. JAMA 2020 (e-pub ahead of print) . Doi: 10.1001/ jama.2020.1585

9 Zhou F, Yu T, Du R, Fan G, Liu Y, Liu Z, et al. Clinical course and risk factors for mortality of adult inpatients with COVID-19 in Wuhan, China: a retrospective cohort study. Lancet 2020 (e-pub ahead of print) . Doi: 10.1016/S0140-6736(20)30566-3

10 Guan WJ, Ni ZY, Hu Y, et al; China Medical Treatment Expert Group for Covid-19. Clinical characteristics of coronavirus disease 2019 in China. N Engl J Med 2020 (e-pub ahead of print) . Doi: 10.1056/NEJMoa2002032

11 Han H, Yang L, Liu R, et al. Prominent changes in blood coagulation of patients with SARS-CoV-2 infection. Clin Chem Lab Med 2020 (e-pub ahead of print) . Doi: 10.1515/cclm-2020-0188

12 Lippi G, Plebani M, Michael Henry B. Thrombocytopenia is associated with severe coronavirus disease 2019 (COVID-19) infections: a meta-analysis. Clin Chim Acta 2020 (e-pub ahead of print) . Doi: 10.1016/j.cca.2020.03.022

13 Page MJ, Pretorius E. A champion of host defense: a generic largescale cause for platelet dysfunction and depletion in infection. Semin Thromb Hemost 2020;46(03):302-319

14 Borges AH, O'Connor JL, Phillips AN, et al; INSIGHT SMART Study Group; ESPRIT Study Group; SILCAAT Scientific Committee. Factors associated with D-dimer levels in HIV-infected individuals. PLoS One 2014;9(03):e90978

15 Ramacciotti E, Agati LB, Aguiar VCR, et al. Zika and chikungunya virus and risk for venous thromboembolism. Clin Appl Thromb Hemost 2019;25:1076029618821184

16 Smither SJ, O'Brien LM, Eastaugh L, et al. Haemostatic changes in five patients infected with Ebola virus. Viruses 2019;11(07): E647

17 Kim SY, Koetzner CA, Payne AF, et al. Glycosaminoglycan compositional analysis of relevant tissues in Zika virus pathogenesis and in vitro evaluation of heparin as an antiviral against Zika virus infection. Biochemistry 2019;58(08):1155-1166 